\title{
The Effect of Transformational Leadership of School Principles, School Committee Participation, Teacher Performance, and School Culture on Children-Friendly School Performance at Public Primary School in Deli Serdang Regency
}

\author{
Jumakir $^{1}$ Sri Milfayetty ${ }^{2}$ Ibnu Hajar $^{3}$
}

\author{
${ }^{1}$ Post Graduated Program at Universitas Negeri Medan, Medan, Indonesia \\ ${ }^{2,3}$ Professor of Universitas Negeri Medan, Medan, Indonesia \\ *Corresponding author. Email: jumakir182@gmail.com
}

\begin{abstract}
The research objectives are to identify and examine: a child-friendly school performance model that is built based on an associative causal relationship between exogenous and endogenous variables; the influence of the principal's transformational leadership on school culture; the effect of school committee participation on school culture; the influence of teacher performance on school culture; the influence of the principal's transformational leadership on the performance of child-friendly schools; the effect of school committee participation on the performance of child-friendly schools; the effect of teacher performance on the performance of child-friendly schools; and the influence of school culture on the performance of child-friendly schools. This research was conducted at a public primary school in Deli Serdang Regency involving 237 public primary schools as samples. The results showed: (1) Child-friendly school performance models were obtained at public primary school in Deli Serdang Regency; (2) the principal's transformational leadership has a direct positive effect on school culture with $\mathrm{p} 41=0.749$; (3) school committee participation has a direct positive effect on school culture with $\mathrm{p} 42=0.562$; (4) teacher performance has a direct positive effect on school culture with $\mathrm{p} 43=0.522 ;(5)$ the principal's transformational leadership has a direct positive effect on the performance of child-friendly schools with p51 = 0.612 and (6) school culture has a direct positive effect on the performance of child-friendly schools with p54 $=0.685$.
\end{abstract}

Keywords: Principal's transformational leadership, School committee participation, Teacher performance, School culture, Child-friendly school performance.

\section{INTRODUCTION}

Education is an important element of a person's life and is a strategic aspect for a country. The nature of education is complex, dynamic, and contextual. Therefore education is not an easy or simple thing to discuss. The complexity of this education illustrates that education is a serious effort, because education involves cognitive, affective, and psychomotor aspects that will shape students as a whole to become fully human. The child-friendly school program is aimed at preparing Indonesia's golden generation in 2045, coinciding with 100 Years of Indonesia's Independence.

Law No. 23 of 2002 article 4 concerning child protection states that children have the right to be able to live, grow, develop, and participate properly in accordance with human dignity, as well as get protection from violence and discrimination. As mentioned above, one of them is participating in a form that is described as the right to have an opinion and have your voice heard. This article implicitly states that a child must feel safe and comfortable during the learning process. One of them is by creating a child-friendly environment, namely creating a safe, comfortable, healthy and conducive atmosphere, accepting children as they are, and respecting children's potential.

The Deli Serdang District Education Office through the Deli Serdang Regent's Decree requires all its fostered education units to play an active role in the 
implementation of Child-friendly School-based education. This is stated in the Decree of the Regent of Deli Serdang No. 192 of 2019 concerning the establishment of a child-friendly district task force. In the implementation in each school, the Education Office of Deli Serdang Regency uses a child-friendly school assessment that focuses on indicators: (1) SRA policy through the MeSRA Sorcery movement; (2) childfriendly teaching and learning process; (3) child-friendly educators and education personnel; (4) child-friendly facilities and infrastructure; (5) the participation of students, and (6) the participation of parents, community institutions (LM), the business world, other stakeholders, and alumni who provide opportunities for children to comfortably learn.

The current condition of the school can be interpreted as a school that does not facilitate and empower children's potential. To empower the potential of school children, of course, must program something that causes the potential of children to grow and develop. The consequences of creating child-friendly schools are not easy because schools must not only create adequate school programs, schools must also create an educational environment. Throughout 2019, the National Commission for Child Protection (Komnas PA) has received complaints of 2,737 cases of violence against children. This figure decreased when compared to the report received in 2018, which was 3,339 cases. This figure is based on data released by the Indonesian Child Protection Commission (KPAI) according to a survey by the International Center for Research on Women (ICRW).

KPAI data also shows a very worrying condition in 2019. The results of the KPAI survey on elementary, junior high, and high school students in Indonesia show: around $21 \%$ or 21 out of 100 high school students have abortions because they are pregnant out of wedlock; around $93 \%$ or 93 out of 100 elementary school students have accessed pornography through their internet cafe or smartphone services; 135 students are victims of violence every month at school; 5 out of 100 high school students contract sexually transmitted diseases from their habit of associating with street prostitutes; around $63 \%$ or 63 out of 100 junior/high school youth have had sex outside of marriage; Sexual violence in schools occurs in 19 provinces, cases of incest (incest) are found in 23 of 34 provinces in Indonesia. Coupled with the heavy curriculum burden,

Based on the data above, it is necessary to have safe and comfortable school conditions for children. Far from acts of violence, bullying, and other discriminatory actions. A safe and comfortable school is a school where the school community is free from fear, conducive to learning and positive relationships between school members. Schools that are supposed to be safe and comfortable places for children to learn have yet to meet these needs. Schools with infrastructure that are not in accordance with the needs of children often make children unsafe and comfortable at school. Teachers as educators who are supposed to provide protection to children are often perpetrators of violence against children. Ariefa's research [1], found that there are still various forms of bullying in Primary Schools, both physical, verbal, and psychological bullying.

To achieve the rights of every child, school principals and education stakeholders must also be able to create an innovation about schools which are the best places to learn by referring to the creation of a Child-friendly School environment. School as a beautiful and fun place that has an impact on increasing students' passion for learning, schools must be safe, create a healthy environment for social interaction with children with the main principle of non-discrimination, giving children the right to freedom to be able to develop every potential they have and giving awards to children. every child, as well as being able to create a conducive academic climate and improve the image of the school.

One of the determining factors, the high and low quality of education and school effectiveness is the transformational leadership of the principal. This is understandable because leadership not only takes the initiative, but also means managerial ability, namely the ability to organize and put things in their place. The relationship of leadership variables to the performance of Child-friendly Schools is shown in Smith's research [2]which states that his leadership style requires dedication from the principal and plays an integral role in developing a great school culture. Principals must skillfully balance school management with building, trusting relationships, and caring through an inspirational approach [3].

Marks and Susan [4] in their research show that there is a significant influence between leadership affecting the performance of Child-friendly Schools. The results of the study show that the issues that arise in the transformational leadership of school principals in developing Child-friendly Schools today are: (1) not yet fully principals have a clear vision in the development of Child-friendly Schools; (2) the way school principals develop Child-friendly Schools has not shown 
satisfactory results; (3) lack of special training on school management; (4) limited efforts to increase managerial leadership professionalism that focus on the needs (ability and skills) obtained are still natural through the process of routine managerial experience,

The success or failure of a school in displaying its performance, much depends on the quality of the transformational leadership of the principal. The principal as an educational leader is required to have high ability and dedication to manage schools, especially to meet the demands of the development of science and technology in order to improve the quality of education. In addition, he needs to analyze various views and tendencies with his own ability, and respond to the problems faced by his subordinates. Although there have been many structural changes to improve the performance of school management, the results have not been so visible. This is because there is a relationship between the success of the quality of education in schools with the quality of school principals. A successful school is a school led by a qualified principal. and vice versa, less successful schools are schools led by less qualified principals. The extent to which the principal is able to display his good leadership style has a direct effect on school performance. School performance is indicated by the climate of school life, school organizational culture, work ethic, teacher work spirit, student achievement, and the discipline of the school community as a whole.

The relationship of leadership variables to school culture is shown in the research of Murtedjo and Suharningsih [5] which states that the results of the study show principals in optimizing a conducive school culture by creating physical school conditions and pleasant socio-emotional conditions, so that teachers are motivated to implement interactive learning, where students are always excited and happy in class. This is expected to improve learning achievement and school quality. Research by Pane and Astuti [6] found that organizational culture, transformational leadership, and compensation or rewards have a significant effect on performance. This can be seen from the transformational leadership variable with a regression coefficient of 0,422 then the compensation variable with a regression coefficient of 0.381 ; and the last is the organizational culture variable with a regression coefficient of 0.120 . Overall, it is known that organizational culture, transformational leadership, compensation or rewards have a significant effect on performance.

The results of research by Elgelal and Noermijati [7] concluded the direct influence of transformational leadership on employees, motivation, job satisfaction, and employee performance. Then investigate the effect of directing employee satisfaction and motivation on employee job performance and employee performance, and to find out that job satisfaction has a direct effect on employee performance. The findings of this study reveal that transformational leadership has a positive and significant effect on employee job satisfaction. Meanwhile, transformational leadership has a significant effect on employee performance through job satisfaction, so that job satisfaction expressed can mediate the effect of transformational leadership on employee performance.

Orabi's research [8] shows that this type of leadership together can influence employee behavior and commitment which leads to an improvement in the work climate and knowledge sharing. The results show that while transformational leadership and its three components - inspirational motivation, intellectual stimulation, and individual consideration - contribute to 81.6 percent of the variance in organizational performance; the idealized influence was not a significant factor contributing to this result. Leaders may need to focus on elements of transformational leadership to improve organizational performance outcomes.

Afzal, et al [9] research identified the effect of transformational leadership on nurse performance in two tertiary care government hospitals, Lahore Pakistan. The results of Wibowo's research [10], it is known that transformational leadership has an effect on teacher performance. Other studies also mention that transformational leadership and organizational culture affect performance. This can be seen from the results of Adinata's research [11], it is known that transformational leadership, organizational culture, has a significant effect on performance. It can also be seen from the research results of Nursyamsi [12] that leadership has a significant influence on performance.

Efforts to develop a school culture that is oriented towards achieving the performance of Child-friendly Schools, school principals can organize and maintain in such a way the continuity of activities in schools. The relationship of school culture variables to the performance of Child-friendly Schools is shown in the research of Etxeberria [13] which states that school culture is related to teacher commitment to educational work, involvement, teamwork, and participatory school management in the Basque Autonomous Region of Spain. The results suggest to expand our understanding of culture beyond peaceful coexistence between students, 
and to include processes of teamwork and democratic participation in plans for peaceful coexistence. Research conducted by Kwong [14] confirms that among the cultural variables at the school level.

The achievement of the goals of Child-friendly Schools (SRA) is also influenced by teacher performance factors. The involvement of teacher performance variables in schools in improving the quality of education in schools is shown in the research of Akert and Barbara [15] which concludes that there are significant differences in teacher involvement in developing the quality of learning services in schools. Another study which shows that there is a significant influence between teacher performance on improving school quality is disclosed by Bredeson and Johansson [16] stating that teachers have a significant influence on school development. Bredeson and Johansson identify the role of teachers in improving school quality, namely: (1) instructional leaders and learners in the classroom; (2) the creation of a learning environment and (3) direct involvement in its professional design, delivery, and content development.

The performance of teachers as the main actors in providing education in schools plays an important role in realizing effective learning in schools, as an effort towards Child-friendly Schools. The relationship between teacher performance variables in schools and the performance of Child-friendly Schools is shown in Panigrahi's research [17] identifying schools that are more effective and less effective; to find out the differences between more effective and less effective schools in terms of physical facilities, principal performance, teacher and student performance. The results of further research show that there is no simple combination of factors that can produce an effective school. Schools are declared effective in terms of classroom teaching.

Efforts to realize Child-friendly Schools must get the full support of the school committee. The school committee, which is the parent's representative in the service and quality assurance efforts of education, must be able to play an active role. The relationship of leadership variables to school committee participation is shown in Singh's research [18] finding six dimensions of effective school leadership identified from the literature: (1) vision development and goal setting; (2) creating a positive school culture; (3) support teachers and students; (4) develop leadership among staff; (5) managing resources; and (6) lead for continuous improvement. All principals identified challenges in their work, but principals from low-performing schools identified more challenges.

Research by Ahmad and Hamdan [19] states that parental participation in Pakistan has affected the quality of education in Pakistan. The results show that in Pakistan the principal does not play an active role in promoting parental participation. Principals at the secondary school level do not know how to involve parents in the education process. They lack the motivation and management skills to involve parents in the educational process. Further research found that principals perceive parental involvement in education as a distraction in school affairs. Ironically, the principal accepts that parental participation is very important for education. On the basis of this research it is recommended that school principals should be given comprehensive training on the concept of parental participation in education. For this purpose strong parent associations should be established and actively monitored.

Good school committee participation will make it easier for schools to create effective Child-friendly Schools. This means that schools can guarantee quality services in providing education to all students. Mohajeran and Alireza [20] research stated that the form of school governance (especially decision making) has an impact on school effectiveness with reference to parental involvement, planning, budgeting, teacher professional development, school facilities and resources, as well as student outcomes. This study finds that it is not so much the structure but the centrality of the principal and the way in which the principal understands his or her role in relation to others that has the most impact on school governance. Another study which shows that there is a significant effect between school committee participation and the performance of Child-friendly Schools, stated that Thapa et al [21] stated that the results of the study focused on reforming school culture as an evidencebased school improvement strategy that supports students, parents/guardians, and school personnel, learn and work together to create safer, more supportive and profitable schools. There are five important dimensions of school culture: safety, relationships, teaching, learning, institutional environment, and school process improvement.

The Deli Serdang Regency Government through the Education Office, formulated a program that brought together all stakeholders in a concept that was considered capable of knitting all programs into a policy with the birth of the Child-friendly School concept based on 
"Creating Child-friendly Schools with Parent and School Communities" which later became popular. with the Lucky MeSRA. The Acceleration of Child-friendly Schools (SRA) in Deli Serdang Regency, which is an intense program triggered and driven by the current education office, is very much supported by the MeSRABertuah movement, in its realization considering that SRA is an important and high point in improving education in Deli Serdang Regency. Analyzing the SRA and the Lucky MeSRA in Deli Serdang, the main point is the involvement of parents and the community. The participation of school students' families is an indicator of assessment and success. Comprehensively, with ongoing family education development. Education for parents and the community that is now running must continue to be improved, because it has a major impact on the success of education. Moreover, in the success of SRA based on child protection. SRA will be nothing if parents are not involved in it. School is a safe and fun place for children, as a second home, of course, school cannot run alone. For this reason, the existence of MeSRA Bertuah is the main driver to oversee the fulfillment of children's rights and protection throughout Indonesia, especially the education aspect by ensuring that all school-age children go to school. The Lucky MeSRA can be a shield in protecting children from the dangers that threaten at school, be it narcotics, violence, pornography, unhealthy food, unhealthy environment and so on. With the Lucky MeSRA activity, it is hoped that the Deli Serdang Regency Government in realizing Child-friendly Schools will create the best generation.

From the background stated above, it can be seen that there is a relationship between the transformational leadership of school principals, school committee participation, teacher performance, and school culture on the performance of Child-friendly Schools. In this regard, the researcher feels it is important to conduct a research entitled: the effect of transformational leadership of school principals, school committee participation, teacher performance, and school culture on the performance of Child-friendly Schools in SD Negeri Deli Serdang Regency.

\section{AIM AND METHODOLOGY}

This research was conducted at a public elementary school in the Deli Serdang Regency Education Office. The time of the research was carried out from September 2020 to January 2021. This research is a quantitative research type of path analysis (Path Analysis). The pattern of interrelationships between school principal transformational leadership research variables (X1), school committee participation (X2), teacher performance (X3), and school culture (X4) on childfriendly school performance (X5).

The population in this study were all principals of public primary schools at the Education Office of Deli Serdang Regency is 582 persons. Determination of the number of samples is done randomly through lottery. The sample size was taken based on the formula stated by Slovin in Umar [22], which gave a total sample of 237 people.

In this study, there are five variables, namely: childfriendly school performance, transformational leadership of school principals, school committee participation, teacher performance, and school culture. Child-friendly school performance is an action taken by schools in order to create a learning environment that can encourage children's growth and development with a sense of security, worth, and fun in developing their potential well, which is shown from: SRA policies through the Sorcerer MeSRA movement, friendly teaching and learning processes children, educators and child-friendly education staff, child-friendly facilities and infrastructure, student participation, and participation of parents, community institutions (LM), the business world, other stakeholders, and alumni who provide opportunities for children to comfortably learn.

The principal's transformational leadership is the leader's ability to manage all existing resources, and is able to move or influence his subordinates by making changes, so that they can organize child-friendly schools well, which is shown from: having charisma, inspiring subordinates, stimulating subordinates intellectually, and show concern for the individual. The participation of the school committee is a form of concern for parents and the community together with the school as an effort to advance and improve the quality of education in schools, which is shown from: givers of considerations, supporters, controllers, and mediators.

Teacher performance is the work behavior displayed by teachers in schools in every teaching and learning process in the classroom regarding the extent to which the planned learning activities are implemented, which is shown from: planning learning, implementing learning, and evaluating learning. School culture is the daily behavior of the entire school community in carrying out their duties to act according to the rules set by the school, which are indicated by: innovation and risk taking, attention to detail, results orientation, people orientation, team orientation, aggressiveness, and stability. 


\section{RESULT AND DISCUSSION}

Based on the values of the correlation coefficient and path coefficient obtained from the calculation results, then the direct and indirect effects of exogenous variables on endogenous variables are calculated as follows:

\subsection{Principal's Transformational Leadership on School Culture}

Based on hypothesis testing with a path coefficient of $\mathrm{p} 41=0.749$. The research results obtained also support the research conducted by Murtedjo and Suharningsih [23]; Yadessa [24]; and Tajasom and Zainal [25] that the principal's transformational leadership has a significant effect on school culture. One of the dominant indicators of improving the principal's transformational leadership is intellectual stimulation of subordinates. The ability to inspire will increase the aggressiveness of teachers and employees in creating a school culture that is in line with the values agreed by the school community. Every teacher and employee will work well personally and as a team in doing various things at school that support the creation of a conducive school culture.

Efforts to stimulate the intellectuals of teachers and employees are carried out by principals with the aim of increasing their attention to the details of work in schools. With this effort, everyone in the school will get used to working properly to build a school culture that supports every learning process. In addition, the principal's ability to stimulate will be able to increase the aggressiveness of teachers and employees in achieving school goals.

\subsection{School Committee Participation in School Culture}

Based on hypothesis testing with a path coefficient of $\mathrm{p} 42=0.562$. The results obtained also support the research conducted by Lubis and Haidir [26], Fitriati, Rahmat, and Unifah [27]; and Ahmad and Hamdan [19] that school committee participation has a significant effect on school culture. School committee participation can be seen from the ability to provide support to schools. School committee participation is carried out by providing support for every activity planned by the school.

This support can be carried out by the school committee with its readiness to provide financial and labor assistance for the implementation of a good school culture. The readiness of the school committee to always attend work meetings at school can be carried out, with the intention that there is an understanding of what school culture is expected of parents at school. In addition, the support of the school committee in improving school culture can also be carried out with support for increasing the ability of teachers and employees to ensure the implementation of a good school culture.

\subsection{Teacher Performance on School Culture}

Based on hypothesis testing with a path coefficient of $\mathrm{p} 43=0.522$. The results obtained also support the research conducted by Akert and Barbara [15]; Emmanouil, Anastasiou, and Loukeri [28]; Okoli [29]; Peacock [30]; and Bredeson and Johansson [16] that teacher performance has a significant effect on school culture. Teacher performance can be seen from their ability to plan learning in schools. Teachers in carrying out work in schools generally consist of three main activities, namely: learning planning activities, implementing learning activities, and evaluating learning activities.

Teacher performance in planning learning can be done by planning each learning process that leads to innovative learning, namely learning that provides freedom of thought and creativity to each student. The innovative thinking that is formed will make it easier for students to participate in activities to improve the school culture that they want to develop. Thus, teachers must be able to plan innovative and fun learning that educates students to be independent in activities at school. Innovative learning provided by teachers must be oriented towards teamwork in the classroom in creating a conducive learning culture in schools. In other words, every lesson plan must be directed at achieving the improvement of school culture.

\subsection{Principal's Transformational Leadership on Child-friendly School Performance}

Based on hypothesis testing with a path coefficient of $\mathrm{p} 51=0.612$. The results obtained also support the research conducted by Barrett and Robert [31]; Smith [2]; Oliveira and Cynthia [3]; Marks and Susan [4]; and Ardansyah [32] that the principal's transformational leadership has a significant effect on the performance of child-friendly schools. The principal's transformational leadership can be seen from his ability to stimulate the intellectuals of his subordinates. The principal can ask the teacher to show an exemplary attitude in dealing with students at school. 
The principal also inspires teachers to use learning methods that excite students when learning. If possible, the principal makes rules that require teachers to use contextual learning by using the environment around the classroom. In addition, the principal during a work meeting can ask the teacher to rearrange the class arrangement according to the needs of the students and

Based on hypothesis testing with a path coefficient of p54 $=0.685$. The research results obtained also support the research conducted by Maxwell et al [33]; Tubbs and Mary [34]; Etxeberria [13]; Brault, Michel, and Asabelle [35]; and Kwong [14] that school culture has a significant effect on the performance of childfriendly schools. School culture can be seen from the orientation of school program results. School programs that are prepared must be directed at improving school culture based on changes in students' attitudes. Changes in students' attitudes that lead to goodness in line with school culture must be a priority for school programs.

This is because school culture must be able to build good attitudes in students, both when in class following learning and when outside the classroom. To realize this, the orientation of learning outcomes must be seen from the lesson plans prepared by the teacher and the arrangement of the school environment that supports its implementation. Structuring the environment around the classroom according to student needs will make it easier for schools to instill good attitudes in students. Based on the learning materials to be provided. It aims to avoid boredom in students when studying in class.

\subsection{School Culture on Child-friendly School Performance}

The results of theoretical studies and the results of the analysis of the structure of the causal associative relationship between exogenous variables and endogenous performance variables. A child-friendly school performance model was found that fit perfectly with the data to be implemented adaptively in public Primary Schools in Deli Serdang Regency.

The performance model for Child-friendly Schools, the findings of this study explain that improving the performance of child-friendly schools can be built through strengthening the transformational leadership of school principals, strengthening school committee participation, teacher performance, and a school culture that can improve performance. implemented adaptively at public Primary Schools in Deli Serdang Regency. (see Fig. 2) The strengthening of the principal's transformational leadership accompanied by the strengthening of school committee participation causes teacher performance and school culture to be higher, which in turn will make the performance of implementing child-friendly schools run well.



Figure 2. Research Novelty 
The implementation of child-friendly schools requires the availability of a school culture that fully supports child-friendly school activities. In this case, school culture is built by the principal's transformational leadership, teacher performance, and school committee participation. The principal's transformational leadership can direct teachers to show exemplary attitudes in dealing with students at school. This exemplary attitude of the teacher is shown both when the teacher is inside and outside the classroom. In addition, the principal guarantees the creation of a school culture that supports the creation of guarantees for the implementation of child-friendly schools. The development of a school culture to the extent possible to support the implementation of child-friendly schools should emphasize the right of all children to free and compulsory education in settings that encourage participation and attendance; humane and fair institutional discipline; develop personality, develop pupils' talents and abilities to their fullest potential; human rights respect for children and basic freedoms; respect and encourage the child's cultural identity, language and values, as well as the national culture, and values of the country in which the child lives; and prepare children to live as free, responsible individuals who respect other people, and the natural environment. For this reason, schools must create a conducive atmosphere so that children feel comfortable and can freely express themselves according to their potential. The transformational direction of the principal's policy can be seen from the following aspects: human rights respect for children and basic freedoms; respect and promote the child's cultural identity, language and values, as well as the national culture, and values of the country in which the child lives; and prepare children to live as free, responsible individuals who respect other people, and the natural environment. For this reason, schools must create a conducive atmosphere so that children feel comfortable and can freely express themselves according to their potential. The transformational direction of the principal's policy can be seen from the following aspects: human rights respect for children and basic freedoms; respect and encourage the child's cultural identity, language and values, as well as the national culture, and values of the country in which the child lives; and prepare children to live as free, responsible individuals who respect other people, and the natural environment. For this reason, schools must create a conducive atmosphere so that children feel comfortable and can freely express themselves according to their potential. The transformational direction of the principal's policy can be seen from the following aspects: Schools must create a conducive atmosphere so that children feel comfortable and can freely express themselves according to their potential. The transformational direction of the principal's policy can be seen from the following aspects: Schools must create a conducive atmosphere so that children feel comfortable and can freely express themselves according to their potential. The transformational direction of the principal's policy can be seen from the following aspects:

- Appropriate school program. School programs should be adapted to the child's world, meaning that the program is adapted to the stages of growth and development of children. Children do not have to be forced to do something, but with this program children are automatically encouraged to explore themselves. An important factor that needs to be considered by schools is the active participation of children in programmed activities, so it is hoped that participation will grow because it is in accordance with the needs of children. The principal must be able to ensure that a teacher can show: (a) a sense of love for children (having a sense of love for the children), (b) understanding the world of children (having a sense of love for the children), and (c) being able to approach children with appropriate (having appropriate approach).

- $\quad$ Supportive school environment. The atmosphere of the school environment should be a safe place for children to learn about life, especially schools that program teaching and learning activities until the afternoon. The atmosphere of children's activities in the community is also programmed in schools, so that children still get the experiences that they should get in the community. For children, an environment that allows them to play is very important, because playing for children is a part of their life. In addition, the creation of a clean environment, access to healthy drinking water, free of germs, and adequate nutrition are important factors for the growth and development of children.

- $\quad$ Aspects of adequate facilities and infrastructure. The main facilities and infrastructure needed are related to the learning needs of children, they do not have to be expensive but according to the needs of children. The existence of a safe zone for going to school, the existence of a smoking bill-free area, inclusive education, are also important factors that 
schools must pay attention to. Schools also need to organize an attractive, attractive, impressive school and classroom environment, parenting patterns, and individual approaches, so that schools become a safe, comfortable and enjoyable place.

Child-friendly schools aim to build a learning environment, where children are motivated and able to learn. The school community is friendly and open to the health and safety needs of students. Child-friendly schools aim to create a learning environment that encourages children to grow and develop in a safe, decent, and fun way to get the right to education and a good environment.

\section{CONCLUSION}

\subsection{Conclusion}

- The principal's transformational leadership has a significant effect on school culture at public primary schools in Deli Serdang Regency. Thus, the principal's transformational leadership can improve the principal's school culture.

- School committee participation has a significant effect on school culture at public Primary Schools in Deli Serdang Regency. Thus, the participation of the school committee can improve the school culture of the elementary school principal.

- Teacher performance has a significant effect on school culture at public primary schools in Deli Serdang Regency. Thus, teacher performance can improve the performance of child-friendly schools.

- The principal's transformational leadership has a significant effect on the performance of childfriendly schools at public primary schools in Deli Serdang Regency. Thus, the principal's transformational leadership can improve the performance of child-friendly schools.

- School committee participation has a significant effect on the performance of child-friendly schools at public primary schools in Deli Serdang Regency. Thus, school committee participation can improve the performance of child-friendly schools.

- Teacher performance has a significant effect on the performance of child-friendly schools at public primary schools in Deli Serdang Regency. Thus, teacher performance can improve the performance of child-friendly schools.
- School culture has a significant effect on the performance of child-friendly schools at public primary schools in Deli Serdang Regency. Thus, school culture can improve the performance of childfriendly schools.

\subsection{Implication}

a. Implications for the Deli Serdang District Education Office

- Carry out monitoring activities in public primary schools by paying attention to the level of achievement of child-friendly schools based on aspects: transformational leadership of school principals, school committee participation, teacher performance, and school culture.

- Prepare a program for strengthening school principals to strengthen the implementation of childfriendly schools, in the form of school management guidance, seminars, training, comparative studies, increasing education levels, and so on.

- Prepare a program to increase parental participation in school committees to support and supervise the implementation of child-friendly schools by considering: (1) the participation of school committees in decision-making meetings at the education office; and (2) forming parent representatives to oversee the implementation of child-friendly schools in public schools.

b. Implications for Principals

- Continue to improve the ability to inspire teachers and education personnel in schools to achieve the implementation of child-friendly schools as a form of transformational leadership of the principal as a leader. Principals can increase knowledge through the desire to increase their quality in leading schools well, with quality, and thinking ahead.

- Continue to support the policies of the Deli Serdang Education Office and direct teachers and education staff to build connections with school committees that are conducive to the implementation of childfriendly schools. The awakening of good school committee participation will direct schools towards achieving educational goals which are actually in line with the policies of the Deli Serdang Education Office.

- Continue to foster teacher performance with a sense of pleasure in working wholeheartedly to achieve school goals, as well as improve school culture by 
providing working conditions that support the achievement of child-friendly school goals.

\subsection{Suggestion}

The Deli Serdang Regency Education Office should carry out monitoring activities for the principals of public Primary Schools through measurable actions on: the transformational leadership of the principal in leading and the ability of the principal to build good school committee participation. The Education Office can also prepare a program for strengthening school principals' transformational leadership, through: school management assistance programs, seminars and training for continuous principal strengthening, and conducting comparative studies to provide information on the implementation of child-friendly schools. In addition, the Education Office must prepare a selection program for school principals, through:

Principals of public Primary Schools in Deli Serdang Regency should continue to improve their ability to lead schools, through: implementing transformational leadership in schools and continuing education in the field of school management. In addition, school principals continue to support government policies in implementing child-friendly schools, through: building conducive school committee participation in schools, and communicating regularly with the education office regarding changes in the school environment.

Other researchers should use the results of this study to conduct further research in realizing the implementation of child-friendly schools, by increasing the research sample and covering a wider area.

\section{REFERENCES}

[1] Ariefa, Efianingrum, "Mengurai Akar Kekerasan (Bullying) di Sekolah," J. Din., 2009.

[2] B. S. Smith, "The Role of Leadership Style in Creating a Great School," SELU Res. Rev. J. (SRRJ, vol. 1, no. 1, pp. 65-78, 2016, Accessed: Oct. 05, 2021. [Online]. Available: https://selu.usask.ca/documents/research-andpublications/srrj/SRRJ-1-.

[3] Oliveira, A.C.P. and C. P. De Carvalho, "Public school management, leadership, and educational results in Brazil," Rev. Bras. Educ., vol. 23, 2018, doi: 10.1590/S1413-24782018230015.

[4] Marks, H.M and S. M. Printy, "Principal Leadership and School Performance: An
Integration of Transformational and Instructional Leadership," Educational Administration Quarterly, vol. 39, no. 3. 2003, doi: $10.1177 / 0013161 X 03253412$.

[5] Murtedjo and Suharningsih, "The role of principal in optimizing school climate in primary schools," J. Phys. Conf. Ser., vol. 953, no. 1, Feb. 2018, doi: 10.1088/1742-6596/953/1/012179.

[6] Pane, J., D. Sih, and D. Astuti, "Pengaruh Budaya Organisasi, Kepemimpinan Transformasional, Dan Kompensasi Terhadap Kinerja Karyawan (Studi pada Kantor Telkom Divre IV di Semarang)," J. Telaah Manaj., vol. 6, no. 1, pp. 67-85, 2009.

[7] Elgelal, K.S.K. and N. Noermijati, "The Influences of Transformational Leaderships on Employees Performance (A Study of the Economics and Business Faculty Employee at University of Muhammadiyah Malang)," APMBA (Asia Pacific Manag. Bus. Appl., vol. 3, no. 1, pp. 48-66, Sep. 2015, doi: 10.21776/UB.APMBA.2014.003.01.4.

[8] Orabi, T. G. A., "The Impact of Transformational Leadership Style on Organizational Performance: Evidence from Jordan," Int. J. Hum. Resour. Stud., vol. 6, no. 2, 2016, doi: 10.5296/ijhrs.v6i2.9427.

[9] Afzal, M., A. Waqas, R. Kousar, K. Perveen, and M. Hussain, "The Effect of Transformational Leadership on Nurses' Performance," Texila Int. J. Nurs., vol. 2, no. 2, 2016.

[10] Wibowo, E. A., and E. Prasetyo, "Analisa Pengaruh Gaya Kepemimpinan Terhadap Motivasi Kerja Karyawan Di Restoran X," J. Hosp. dan Manaj. Jasa, vol. 3, no. 1, pp. 354-370, Jan. 2015, Accessed: Oct. 06, 2021. [Online]. Available: http://publication.petra.ac.id/index.php/manajeme n-perhotelan/article/view/2856.

[11] Adinata, U. W. S., "Pengaruh Kepemimpinan Transformasional, Motivasi, Dan Budaya Organisasi Terhadap Kinerja Karyawan Kjks Bmt Tamzis Bandung, STIE Pasundan Bandung " $J$. Ekon. Bisnis Entrep., vol. 9, no. 2, pp. 136-157, 2015.

[12] Nursyamsi, I., "Pengaruh Kepemimpinan, Pemberdayaan, dan Stres Kerja Terhadap Komitmen Organisasional serta dampaknya terhadap Kinerja Dosen," Conf. Business, Accounting, Manag., vol. 1, no. 2, pp. 405-423, Oct. 2021, Accessed: Oct. 05, 2021. [Online]. 
Available:

http://jurnal.unissula.ac.id/index.php/cbam/article/ view/147.

[13] Etxeberria, F., N. Intxausti, and V. Azpillaga, "School Climate in Highly Effective Schools in the Autonomous Region of the Basque Country (Spain)," REICE. Rev. Iberoam. sobre Calidad, Efic. y Cambio en Educ., vol. 15.4, 2017, doi: 10.15366/reice2017.15.4.001.

[14] Kwong, D. and J. R. Davis, "School Climate for Academic Success: A Multilevel Analysis of School Climate and Student Outcomes," J. Res. Educ., vol. 25, no. 2, pp. 68-81, 2015.

[15] Akert, N and B. N. Martin, "The Role of Teacher Leaders in School Improvement through the Perceptions of Principals and Teachers," Int. J. Educ., vol. 4, no. 4, Dec. 2012, doi: 10.5296/IJE.V4I4.2290.

[16] Bredeson, P. V., "The School Principal's Role In Teacher Professional Development," J. In-Service Educ., vol. 26, no. 2, pp. 385-401, 2000, doi: $10.1080 / 13674580000200114$.

[17] Panigrahi, M. R., "School Effectiveness at Primary Level of Education in Review to Classroom Teaching," International Journal of Instruction, vol. 7, no. 2, 2014.

[18] Singh, A., "Role of Transformational Leadership in Enhancing Employee Engagement: Evolving Issues and Direction for Future Research through Literature Review," SSRN Electron. J., pp. 878893, 2019, Accessed: Oct. 06, 2021. [Online]. Available: https://ssrn.com/abstract=3316331.

[19] Ahmad, Iqbal and H. bin Said, "Role of school principal in promotion of school home relationship: case of government secondary schools in Khyber Pakhtunkhwa, Pakistan," Int. J. New Trends Educ. Their Implic., vol. 4, no. 1, 2013.

[20] Behnaz, Mohajeran and Alireza Ghaleesi, "Principal Role and School Structure," World Acad. Sci. Eng. Technol., pp. 669-68, 2008, Accessed: Oct. 05, 2021. [Online]. Available: https://citeseerx.ist.psu.edu/viewdoc/download?do $\mathrm{i}=10.1 \cdot 1.306 .5485 \& \mathrm{rep}=\mathrm{rep} 1 \&$ type $=$ pdf.

[21] Thapa, A., J. Cohen, S. Guffey, and A. HigginsD'Alessandro, "A Review of School Climate Research," Rev. Educ. Res., vol. 83, no. 3, pp. 357
385, Sep. 2013, doi: 10.3102/0034654313483907.

[22] Umar, Husein, Metode Penelitian Untuk Skripsi dan Tesis Bisnis. Jakarta: Raja Grafindo Persada, 1996.

[23] Suharningsih and Murtedjo, "Role of Organizational Culture on the Performance Primary School Teachers," J. Educ. Learn., vol. 6, no. 1, p. p95, Nov. 2016, doi: 10.5539/JEL.V6N1P95.

[24] Yadessa, M., “Assessment of School Climate and Leadership Practices: The Case of Four Selected Secondary Schools of Eastern Hararghe Zone, Ethiopia," J. Educ. Pract., vol. 5, no. 37, pp. 7179, 2014, Accessed: Oct. 05, 2021. [Online]. Available:

https://www.iiste.org/Journals/index.php/JEP/artic le/view/18306.

[25] Tajasom, A., and Z. Ariffin Ahmad, 'Principals' leadership style and school climate: teachers' perspectives from Malaysia," Int. J. Leadersh. Public Serv., vol. 7, no. 4, pp. 314-333, Nov. 2011 , doi: 10.1108/17479881111194198.

[26] Lubis, M.J., and I. Jaya, Komitmen Membangun Pendidikan: Tinjauan Krisis Hingga Perbaikan Menurut Teori. Medan: Widya Puspita, 2019.

[27] Fitriati, R., R. Romdana, and U. Rosyidi, "The Practice of the School Principal's Leadership in Sekolah Indonesia Kuala Lumpur (SIKL): The Study of Leadership Styles and Techniques with Cognitive Mapping Approach," Procedia - Soc. Behav. Sci., vol. 115, pp. 258-268, Feb. 2014, doi: 10.1016/J.SBSPRO.2014.02.434.

[28] Emmanouil, K, "The Impact of Leadership on Teachers' Effectiveness," Int. J. Humanit. Soc. Sci., vol. 4, no. 71, 2014.

[29] Okoli, O S, "Major Leadership Roles Of School Principals For Effective Inclusive Education Programme In Nigeria," Natl. J. Incl. Educ., vol. 3, no. 1, 2015.

[30] Peacock, J. S., "Science Instructional Leadership: The Role of the Department Chair," Sci. Educ., vol 23, no. 1, pp. 36-48, 2014, Accessed: Oct. 05, 2021. [Online]. Available: https://files.eric.ed.gov/fulltext/EJ1034762.pdf.

[31] Barrett Robert Breyer, C., "The Influence of Effective Leadership on Teaching and Learning," J. Res. Initiat., vol. 1, no. 2, pp. 11-17, 2014, 
Accessed: Oct. 05, 2021. [Online]. Available: http://digitalcommons.uncfsu.edu/jrihttp://digitalc ommons.uncfsu.edu/jri/vol1/iss2/3.

[32] Ardansyah, M., "Hubungan Antara Gaya Kepemimpinan Kepala Madrasah Dan Kepuasan Kerja Dengan Kinerja Guru Man Tanjung Morawa," Digit. Repos. Univ. Negeri Medan, 2016.

[33] Maxwell, S., K. J. Reynolds, E. Lee, E. Subasic, and D. Bromhead, "The Impact of School Climate and School Identification on Academic Achievement: Multilevel Modeling with Student and Teacher Data," Front. Psychol., vol. 0, no. DEC, p. 2069, Dec. 2017, doi: 10.3389/FPSYG.2017.02069.

[34] Tubbs, J. E and M. Garner, "The Impact Of School Climate On School Outcomes," J. Coll. Teach. Learn., vol. 5, no. 9, Sep. 2008, doi: 10.19030/TLC.V5I9.1230.

[35] Brault, M. C., M. Janosz, and I. Archambault, "Effects of school composition and school climate on teacher expectations of students: A multilevel analysis," Teach. Teach. Educ., vol. 4, no. 4, pp. 148-159, 2014, doi: 10.1016/j.tate.2014.08.008. 